\title{
Indicators to assess goat welfare on-farm in the semiarid region of Brazilian Northeast
}

\section{Luana Oliveira Leite ${ }^{1^{*}}$ Fabiana de Orte Stamm $^{1}$ Rita de Cassia Maria Garcia ${ }^{1}$} 'Programa de Pós-graduação em Ciências Veterinárias, Setor de Ciências Agrárias, Universidade Federal do Paraná (UFPR), Rua dos
Funcionários, 1540, 80035-050, Curitiba, PR, Brasil. Email: luanaoliv.vet@gmail.com. "Corresponding author.

ABSTRACT: In 2015, AWIN Goat Protocol was published in Europe, with indicators that identify welfare level of lactating dairy goats; however, there are no welfare protocols for meat goat. Therefore, the objective of this study was to select animal and resource-based indicators to assess welfare in meat goat in different types of grazing systems in Brazilian semiarid Northeast. Eighteen indicators were selected to evaluate the welfare of meat goat. The knowledge of the welfare degree of these animals is the best way to make improvements and promote a better quality of life to meat goat.

Key words: animal welfare, animal-based measures, quality of life, parameter, protocol.

Indicadores para avaliar o bem-estar de cabras em fazendas na região semiárida do Nordeste brasileiro

RESUMO: Em 2015, o Protocolo AWIN para cabras foi publicado na Europa, com indicadores que identificam o nivel de bem-estar das cabras leiteiras em lactação, no entanto não existem protocolos de bem-estar para cabras de corte. Portanto, o objetivo deste estudo foi selecionar indicadores baseados nos animais e recursos para avaliar o bem-estar em cabras de corte em diferentes tipos de sistemas de pastejo no semiárido do Nordeste brasileiro. Dezoito indicadores foram selecionados para avaliar o bem-estar de cabras. O conhecimento do grau de bem-estar destes animais é o melhor caminho de realizar melhorias e promover uma melhor qualidade de vida para cabras de corte.

Palavras-chave: bem-estar animal, medidas baseadas em animais, qualidade de vida, parâmetro, protocolo.

\section{INTRODUCTION}

According to FAOSTAT (2017), the number of goats worldwide in 2014 was $1,011,251,833$ animals. The main countries that raised goats were mainland China $(185,675,000)$, India $(133,000,000)$, Nigeria $(72,466,698)$, Pakistan $(66,615)$, and Bangladesh $(55,900,000)$. In Brazil, in 2014, the Municipal Livestock Research reported the existence of 8.851.879 goats and the Northeast region had the highest number of these animals, with $91.6 \%$ of the national goat herd (IBGE, 2014).

In Brazil, semiarid region represents $11.53 \%$ of its territory (IBGE, 2005), in which almost $60.0 \%$ of Northeast region is included (SUDENE, 2016) with hot and dry climate, low rainfall (range 280-800 millimeters), with irregular rains concentrated in three to four months, as well as water scarcity (ARAÚJO, 2011). Under these conditions, raising goats especially brought benefits to this region as low initial capital to start this activity, small scale accumulation of income and adaptation to semiarid regions agroecosystems (HOLANDA JUNIOR \& MARTINS, 2007).

Meat goat have a life of six to seven years on-farm, being used while providing healthy offspring, and do not have dystocia or abortions (SEBRAE, 2000). It is recommended that reproductive life of these animals starts around seven to eight months (CODEVASF, 2011). In Brazil, goats are raised in three different systems: extensive, semiintensive and intensive. In Northeast, the main form of raising goats is in extensive system (VOLTOLINI et al., 2011), in which animals are kept in rudimentary facilities, with sanitary management practices rarely used, and feeding on natural pastures, reflecting a low reproductive and high mortality rate. Productivity depends almost exclusively on weather conditions 
and soil fertility (CODEVASF, 2011). Semi-intensive system has a moderate use of technology, with supplemental feed and health management practices. The goals of intensive systems are higher productivity per animal or production per area available, with cultivation and fertilization of pastures, division of pastures in paddocks and breeding season being a frequent management practiced in this system (CODEVASF, 2011).

Studies have shown that it is possible to increase productivity and ensure animal welfare, being each society responsible for defining how animals are raised (MCINERNEY, 2004), and the demand for products that assure welfare of livestock has increased in recent years (BATTINI et al., 2014). In Brazil, consumers from Piracicaba-SP (88\%) (DONOFRE et al., 2013), Rio Verde-GO (66.9\%) (SCHALY et al., 2010) and São Luís-MA (63.9\%) (ANUNCIAÇÃO et al., 2011) would accept paying a higher value for a product with welfare assurance of animals involved.

One way to assess animal welfare is through indicators. Farm animal welfare measures can be divided into behavioural, physiological, health (BROOM \& FRASER, 2010) and zootechnical (APPLEBY et al., 2011). Behavioral measures can be assessed based on abnormal behavior; physiological parameters can be assessed by heart rate, respiratory rate and cortisol measurement; health indicators of the herd can be assessed by incidence and prevalence of diseases, and zootechnical indicators can be assessed by means of body condition score, mortality and birth rates.

In 2015, a protocol was released to assess welfare of lactating adult dairy goats in Europe, the AWIN Goat (Animal Welfare Indicators for Goats), with the goal of use indicators based mainly in animals and available resources to generate data that represent the quality of life in animals (AWIN, 2015a). Currently, there are no indicators to assess the degree of welfare in meat goat. Considering that Brazilian Northeast has the highest concentration of goat herd in Brazil, with specific weather and rainfall conditions, the aim of this review was to identify possible indicators to be applied in the welfare diagnosis of meat goat in this region.

Selection and types of indicators for welfare assessment in meat goat

Assessment of animal welfare requires the use of several indicators that address physical and mental health, besides natural behavior of each species (BLOKHUIS et al., 2010). Parameters for farm animals were defined by two protocols: Welfare Quality $^{\circledR}$, designed for pigs, poultry, dairy and beef cattle (WELFARE QUALITY ${ }^{\circledR}, 2009$ ) and Animal Welfare Indicators (AWIN), created for sheep, dairy goats, horses, donkeys and turkeys (AWIN PROJECT, 2015). Welfare Quality ${ }^{\circledR}$ is defined by four principles and twelve criteria of welfare, with most of them also presented in AWIN protocols (WELFARE QUALITY $^{\circledR}$ 2009; AWIN PROJECT, 2015). Each criterion has welfare indicators that can be observed in more than one principle. Table 1 shows welfare principles, criteria and indicators of AWIN Goat and Sheep (AWIN, 2015a; 2015b).

Parameters or indicators used by AWIN and Welfare Quality ${ }^{\circledR}$ protocols were selected based on validity, ensuring the degree of current animal welfare; confidence, being identified by different observers, regardless of external conditions such as time of day; and feasibility, which applies to farm level (WELFARE QUALITY, 2009; AWIN PROJECT, 2015). There are three types of indicators: animal-based, concerned about physical and mental health; natural behavior of species, concerned about the expression of social behaviors and absence of stereotypies; and resources and management-based, concerned about stocking density, housing conditions and health plans (BLOKHUIS et al., 2010). The last type is used as a questionnaire (WELFARE QUALITY, 2009; AWIN PROJECT, 2015).

In this review, indicators used to diagnose welfare in meat goat does were selected from AWIN Goats and AWIN Sheep protocols (AWIN, 2015a; 2015b). One parameter was suggested by the authors based on studies on health management and conditions of facilities for goats in Brazilian Northeast, in order to increase the level of welfare of these animals (SEBRAE, 2009; CODEVASF, 2011). Rearing systems, besides climate and rainfall characteristics of this region, were considered in the selection of indicators. Table 2 shows a proposal of animal and resources-based indicators to be tested on welfare assessment in meat goat does in Brazilian Northeast.

Animal-based indicators

Body Condition Score (BCS): VILLAQUIRAN et al. (2004) reported that nutritional status of goats can be measured, subjectively, by palpation of the lower back and sternum, aiming to feel the amount of muscle and fat in these areas. Goats with high or low ECC may have systemic diseases and reproductive problems. In semiarid Brazilian Northeast, many animals are fed only with natural vegetation, even in the dry season (ARAÚJO 
Table 1 - Principles and criteria of welfare for sheep and goats, with respective indicators in each category, accordlying to AWIN Goat and Sheep (AWIN, 2015a, b).

\begin{tabular}{|c|c|c|}
\hline Welfare principles & Welfare criteria & Welfare indicators \\
\hline \multirow{6}{*}{ Good feeding } & \multirow{4}{*}{ Appropriate nutrition } & ${ }^{\mathrm{ab}}$ Body Condition Score \\
\hline & & ${ }^{\mathrm{a}}$ Hair coat condition \\
\hline & & ${ }^{\mathrm{a}}$ Queuing at feeding \\
\hline & & ${ }^{\mathrm{b}}$ Score lamb mortality \\
\hline & \multirow{2}{*}{ Absence of prolonged thirst } & ${ }^{\mathrm{a}}$ Queuing at drinking \\
\hline & & ${ }^{b}$ Water availability \\
\hline \multirow{8}{*}{ Good housing } & \multirow[b]{2}{*}{ Comfort around resting } & ${ }^{\mathrm{a} B e d d i n g}$ \\
\hline & & ${ }^{\mathrm{b}}$ Fleece cleanliness \\
\hline & \multirow{3}{*}{ Thermal comfort } & ${ }^{\mathrm{a}}$ Thermal stress \\
\hline & & ${ }^{\mathrm{b}}$ Panting \\
\hline & & ${ }^{\mathrm{b}}$ Access to shade/shelter (outdoors only) \\
\hline & \multirow{3}{*}{ Ease movement } & ${ }^{\mathrm{a}}$ Kneeling at feeding rack \\
\hline & & bStocking density (housed animals only) \\
\hline & & ${ }^{b}$ Hoof overgrowth (housed animals only) \\
\hline \multirow{20}{*}{ Good health } & \multirow{3}{*}{ Absence of injuries } & ${ }^{\mathrm{a}}$ Severe lameness \\
\hline & & ${ }^{\mathrm{b}}$ Body and head lesions \\
\hline & & ${ }^{\mathrm{b}}$ Leg injuries \\
\hline & \multirow{14}{*}{ Absence of disease } & ${ }^{\mathrm{ab}}$ Abscess \\
\hline & & ${ }^{\mathrm{ab}}$ Body Condition Score \\
\hline & & ${ }^{\mathrm{ab}}$ Faecal soiling \\
\hline & & ${ }^{\mathrm{a}}$ Hair coat condition \\
\hline & & ${ }^{\mathrm{ab}}$ Nasal discharge \\
\hline & & ${ }^{\mathrm{a} O b l i v i o n}$ \\
\hline & & ${ }^{\mathrm{ab}}$ Ocular discharge \\
\hline & & ${ }^{\mathrm{a} O \text { Overgrown claws }}$ \\
\hline & & ${ }^{\mathrm{a}}$ Udder asymmetry \\
\hline & & ${ }^{\mathrm{b}}$ Mucosa colour \\
\hline & & ${ }^{\mathrm{b}}$ Lameness \\
\hline & & ${ }^{b}$ Mastitis and udder lesion (lactating ewes only) \\
\hline & & ${ }^{b}$ Respiratory quality \\
\hline & & ${ }^{\mathrm{b}}$ Fleece quality \\
\hline & \multirow{3}{*}{$\begin{array}{l}\text { Absence of pain and pain induced by } \\
\text { management procedures }\end{array}$} & ${ }^{\mathrm{a}}$ Improper disbudding \\
\hline & & ${ }^{\mathrm{a}}$ Severe lameness \\
\hline & & ${ }^{\mathrm{b}}$ Tail length \\
\hline \multirow{9}{*}{ Appropriate behaviour } & \multirow{3}{*}{ Expression of social behaviour } & ${ }^{\mathrm{a}}$ Queuing at feeding \\
\hline & & ${ }^{\mathrm{a}}$ Queuing at drinking \\
\hline & & ${ }^{\mathrm{b}}$ Social Withdraw \\
\hline & \multirow{3}{*}{ Expression of other behaviours } & ${ }^{\mathrm{a}}$ Oblivion \\
\hline & & ${ }^{\mathrm{b}}$ Stereotype \\
\hline & & ${ }^{b}$ Excessive itching \\
\hline & \multirow{2}{*}{ Good human-animal relationship } & ${ }^{\mathrm{a}}$ Latency to the first contact test \\
\hline & & ${ }^{b}$ Familiar human approach test \\
\hline & Positive emotional state & ${ }^{\mathrm{ab}}$ Qualitative Behavior Assessment \\
\hline
\end{tabular}

Legend: ${ }^{a}$ WIN Goat. ${ }^{b}$ AWIN Sheep. ${ }^{\text {ab }}$ AWIN Goat and Sheep (AWIN, 2015a, b).

FILHO, 2006), being supplemented when it is possible (HOLANDA JUNIOR \& MARTINS, 2007).
Queuing at feeding: dairy goats on low-rank hierarchy were observed feeding in a smaller period 
Table 2 - Proposal of 18 indicators to apply in welfare assessment of goat does in different rearing systems.

\begin{tabular}{|c|c|c|}
\hline Indicators / Rearing systems & Extensive, semi-intensive and intensive systems & Exclusively for intensive system \\
\hline \multirow{14}{*}{ Animal-based indicators } & ${ }^{\mathrm{a}}$ Hair coat & \\
\hline & ${ }^{\mathrm{a}}$ Abscesses & \\
\hline & ${ }^{\mathrm{a}}$ Nasal discharge & \\
\hline & ${ }^{\mathrm{a}}$ Oblivion & \\
\hline & ${ }^{\mathrm{a}}$ Queueing at feeding & \\
\hline & ${ }^{\mathrm{a}}$ Thermal stress & \\
\hline & ${ }^{\mathrm{b}}$ Lameness & \\
\hline & ${ }^{\mathrm{b}}$ Body and head lesions & \\
\hline & ${ }^{\mathrm{b}}$ Leg injuries & \\
\hline & ${ }^{\mathrm{b}}$ Familiar human approach test & \\
\hline & ${ }^{\mathrm{ab}}$ Body Condition Score & \\
\hline & ${ }^{\mathrm{ab}}$ Faecal soiling & \\
\hline & ${ }^{\mathrm{ab}}$ Ocular discharge & \\
\hline & ${ }^{\mathrm{ab}}$ Qualitative Behavior Assessment & \\
\hline \multirow{3}{*}{ Resources-based indicators } & ${ }^{\mathrm{b}}$ Water availability & \multirow{3}{*}{${ }^{\mathrm{b}}$ Stocking density } \\
\hline & ${ }^{\mathrm{b}}$ Access to shade and shelter & \\
\hline & ${ }^{\mathrm{c}}$ Cleanliness of facilities & \\
\hline
\end{tabular}

Legend: ${ }^{a}$ Indicators of AWIN Goat. ${ }^{b}$ Indicators of AWIN Sheep. ${ }^{\text {ab }}$ Indicators of AWIN Goat and Sheep (AWIN, 2015a, b). ${ }^{c}$ Indicator proposed by the authors.

and waiting in line for their turn to eat for a longer period when compared to goats in medium and highrank hierarchy (JORGENSEN et al., 2007). These authors also reported that aggressive interactions increase significantly when the number of goats per trough is higher. Brazilian manuals recommend a space of 20 to $30 \mathrm{~cm}$ per adult animal in the trough (EMBRAPA, 2005; SEBRAE, 2009; CODEVASF, 2011). Meanwhile, CODE OF WELFARE (2012) indicates a space of $40 \mathrm{~cm}$ per adult as adequate. This indicator is important in confined systems and when goats have limited access to food.

Hair coat condition: this parameter may indicate the existence of pathologies or diseases on animals (BERG et al., 2009). Dairy goats with matted, rough and scurfy hair had lower ECC, deficiency or excess of minerals and increased presence of abnormal sounds in lungs compared to goats with shiny and homogeneous coat (BATTINI et al, 2015).

Thermal stress: normal respiratory rate in adult goats varies between 15 and 30 breaths per minute (bpm) (PUGH, 2002). Studies reported that thermal neutral zone for goats is between 20 and $30^{\circ} \mathrm{C}$, with critical heat stress at temperatures above $34^{\circ} \mathrm{C}$ (BAÊTA \& SOUZA, 2010). Goats submitted to temperatures above $30^{\circ} \mathrm{C}$ in Paraíba, Brazil, presented an increase in respiratory rate, rectal temperature and sweating rate, with reduction in food intake and water consumption (BRASIL et al., 2000).

Lameness: most reported lameness in goats occurs due to diseases in hooves caused by inadequate nutrition, environmental and anatomical factors (PUGH, 2002), and sickness such as Caprine Arthritis Encephalitis (CAE), sole ulcer, white line abscesses, sole abscesses and hoof overgrowth (NOGUEIRA et al., 2009; AGUIAR et al., 2011). ALENCAR et al. (2010) cited hooves problems in small ruminants, associated with lameness, possibly due to pododermatitis, in farms $(n=63,43.2 \%)$ located in Pernambuco, Brazil.

Abscesses: occurrence of external abscesses in the body, in the region of the lymph nodes, is closely associated with Caseous Lymphadenitis (CL) in small ruminants (SMITH \& SHERMAN, 2009). In Pernambuco, 52,38\% ( $=44)$ goats had abscesses in lymph nodes suggestive of CL (SOUZA et al., 2014) and this disease was prevalent in farms $(\mathrm{n}=85,66.9 \%)$ in Ceará, Brazil (PINHEIRO et al., 2000).

Body and head lesions: barbed wire and wood splinters were reported by stock people from Maranhão, Brazil, as causes of injuries in goats, and a gateway for ticks and subsequent myiasis (BRITO et 
al., 2005). In this study, tick larvae were reported in head, neck, belly and perianal region.

Leg injuries: occurrence of alopecia region, scabbed and swelling areas on the joints of legs in sheep may be indicative of injury, arthritis or animals lying on hard surfaces for a prolonged time (AWIN, 2015b), and can be also be presented in goats (PUGH, 2002). Also, in goats, arthritis is a symptom of CAE, especially observed in adults (NOGUEIRA et al., 2009).

Faecal soiling: this indicator measures presence of feces in anal region. Occurrence of diarrhea in goats is associated with copper deficiency, sudden change in diet, rumen acidosis, nematodes and cestodes infections (PUGH, 2002). Diarrhea caused by gastrointestinal worms was reported in farms ( $n=100,78.7 \%)$ with goats in Ceará, Brazil (PINHEIRO et al., 2000).

Nasal discharge: dairy goats affected by tuberculosis, caused by Mycobacterium tuberculosis complex, showed bilateral nasal discharge (MELO et al., 2012.). Contagious caprine pleuropneumonia, Parainfluenza type 3, Oestrus ovis larvae, tumors, foreign bodies are other causes of this clinical signs in small ruminants (PUGH, 2002; RUFFIN, 2001). In Pernambuco, it was reported that in $63.3 \%$ of the farms ( $n=93$ ) with small ruminants the animals had nasal discharge (ALENCAR et al., 2010).

Ocular discharge: this symptom is observed in bacterial infections such as infectious keratoconjunctivitis (RUFFIN, 2001) in goats. Keratoconjunctivitis was reported in farms $(n=37$, 29.1\%) with goats in Ceará (PINHEIRO et al., 2000). Ocular changes suggestive of keratoconjunctivitis were also reported in farms $(\mathrm{n}=114,77.6 \%)$ with small ruminants in Pernambuco (ALENCAR et al., 2010).

Oblivion: goats are gregarious animals and only isolate from the herd in moments before delivery (LICKLITER, 1985), or due to health problems, standing immobile and sometimes facing part of the housing structures, according to reports from farmers and technicians (BATTINI et al., 2014). Animals in this situation are usually isolated mental or physically, even during activities that should be synchronized (AWIN, 2015a).

Familiar human approach test: this test evaluates the level of fear in animals and is determined by previous human-animal interaction (MATTIELLO et al., 2010). Animal's reaction, after a human being walking toward him, is measured (AWIN, 2015b). In dairy goats, it was used in animals in extensive system (MATIELLO et al., 2010). In meat goat, this test should be applied due to commonly less daily contact with humans when compared to dairy goats.

Qualitative Behaviour Assessment: this species-specific indicator seeks to identify animal emotions through it behavior expression and body posture (WEMELSFELDER et al., 2000). Descriptors as agitated, alert, bored, curious, relaxed were selected to add qualitative information to welfare diagnosis of dairy goats (AWIN, 2015a). Other descriptors can be studied and included as a way to make this indicator more representative to meat goat.

\section{Resources-based indicators}

Water availability: a constant supply of water for small ruminants is critical to regulating body temperature, especially in Brazilian Northeast semiarid (ARAÚJO et al., 2011). In addition, these authors reported that provision of water points and ease access to them are important factors, especially in dry periods. Water quality should be considered because contaminants such as bacteria, viruses and protozoa are transmitted to animals through this vehicle, being important to assess the cleanliness of water points (AWIN, 2015b).

Cleanliness of facilities: a study conducted in Brazilian Northeast reported that few producers ( $n=18,14.4 \%$ ) perform daily cleaning of facilities, being more common this practice be performed in periods longer than one week $(n=86,68.8 \%)$ (ALENCAR et al., 2010) or every 15 days $(n=11$, 61.1\%) (FILGUEIRA et al., 2009). ALENCAR et al. (2010) reported that the most prevalent type of floor was bare soil ( $\mathrm{n}=83,74.8 \%)$, making it difficult to clean; however, producers performed it by sweeping and applying whitewash. This indicator is also important in extensive system because animals spent all night in facilities.

Stocking density: individual space is important in management of goats, particularly in intensive systems, because it reduces the frequency of aggressive interactions between animals (BARROSO et al., 2000). Brazilian manuals recommend the area of $1 \mathrm{~m}^{2}$ per doe (EMBRAPA, 2005; SEBRAE, 2009; CODEVASF, 2011); however, this is in disagree with the CODE OF WELFARE (2012), which states that goats should have a space of $2 \mathrm{~m}^{2}$ per animal when kept in stalls.

Access to shade and shelter: CODE OF WELFARE (2012) reported that goats kept on pasture, in absence of shadow, have higher water consumption, reduction of grazing behavior, increased respiratory rate, with mouth opening and tongue protrusion in extreme cases, indicating heat 
stress. Shelter is important to ensure that animals stay dry, out of the wet soil, and protected from wind. Animals allocated in hot and dusty environments are more prone to develop pneumonia, in absence of shadow.

Meat goat does and rearing systems in Brazilian Northeast were considered on the selection of these indicators to assess animal welfare. Most animal-based parameters were selected from AWIN Goat because this protocol was specifically developed for this species. Indicators such as "queuing at drinking", "severe lameness", "udder asymmetry", "improper disbudding" were excluded because they are more directed to dairy goats in intensive and semi-intensive rearing systems (AWIN, 2015a). Inclusion of AWIN Sheep indicators, such as "lameness", "body and head lesions", "leg injuries," "panting", "familiar human approach test", "water availability", "access to shade and shelter", "stocking density" (AWIN, $2015 \mathrm{~b}$ ) occurred because this protocol has been developed for different types of rearing systems, including extensive ones, which is more relevant to meat goats in Northeast of Brazil. A new indicator, "cleanliness of facilities", was included because of its possible impact on animal health. Directed studies to prove validity, reliability and feasibility of these indicators in meat goat are needed. These indicators could also be used to diagnose welfare in bucks, but studies regarding their behavior and specific housing conditions are important to select the most relevant ones.

\section{CONCLUSION}

Animal welfare needs to be included in goat breeding as a way to improve goats' living conditions and the quality of products, being this already requested by external markets, as some countries in Europe. The selection of specific indicators to assess the welfare of meat goat is the first step to discuss the elaboration of a specific welfare protocol for goat in the semiarid region of Brazilian Northeast. Welfare assessments detect present problems in the animals' life and can help in the search for improvements in the productive chain, being valuable to bring development to goat breeding in Brazilian Northeast. Along with the proposed indicators, others as presence of aggressive behavior, stereotypies, coughing and vulvar discharge could be included. The indicators proposed are feasible and must be tested in meat goat in the semiarid region of Brazilian Northeast to verify its validity and reliability and to generate studies to elaborate a specific welfare protocol for meat goats.

\section{REFERENCES}

AGUIAR, G.M.N et al. Foot root and other foot root diseases of goat and sheep in the semiarid region of northeastern Brazil. Pesquisa Veterinária Brasileira, v.31, p.879-884, 2011. Available from: $<$ http://www.scielo.br/pdf/pvb/v31n10/v31n10a08.pdf $>$. Accessed: May 06, 2016

ALENCAR, S.P. et al. Sanitary profile of the goat and sheep breeding of the hinterland of Pernambuco. Ciência Animal Brasileira, v.11, p.131-140, 2010. Available from: <http://revistas. bvs-vet.org.br/cab/article/viewFile/8587/8949>. Accessed: May 09, 2016. doi: 10.5216/cab.v11i1.4051

ANUNCIAÇÃO, A.R.A. et al. Animal welfare production: perception of breeders, handlers, consumers, teachers and scholars at the Universidade Estadual do Maranhão. In: CONBRAVET, 38., 2011, Florianópolis, Brazil. Proceedings... Florianópolis: CONBRAVET, 2011. Available from: <http://www.sovergs.com.br/site/38conbravet/ resumos/956.pdf>. Online. Accessed: Apr. 29, 2016.

APPLEBY, M.C et al. Animal welfare. Wallingford: CABI Publishing, 2011. 344p.

ARAÚJO, G.G.L et al. A água nos sistemas de produção de caprinos e ovinos. In: VOLTOLINI, T.V. Produção de caprinos e ovinos no Semiárido. Petrolina: EMBRAPA SEMIÁRIDO, 2011. Cap.3, p.69-94.

ARAÚJO, S.M.S. A região semiárida do nordeste do Brasil: questões ambientais e possibilidades de uso sustentável dos recursos. Rios Eletrônica, n.5, p.89-98, 2011. Available from: $<$ http://www.fasete.edu.br/revistarios/media/revistas/2011/a regiao_semiarida_do_nordeste_do_brasil.pdf $>$. Acessed: Apr. $25,20 \overline{16}$.

ARAÚJO FILHO, J.A. Aspectos zooecológicos e agropecuários do caprino e do ovino nas regiões Semi-áridas. Sobral: EMBRAPA, 2006. 28p. (Documentos 61).

AWIN. Animal welfare indicators for goats, 2015a. Online. Available from: <http://www.animal-welfare-indicators.net/site/ flash/pdf/AWINProtocolGoats.pdf>. Accessed: Apr. 05, 2016.

AWIN. Animal welfare indicators for sheep, 2015b. Online. Available from: <http://www.animal-welfare-indicators.net/site/ flash/pdf/AWINProtocolSheep.pdf>. Accessed: Apr. 05, 2016.

AWIN PROJECT. Animal welfare indicators, 2015. Online. Available from: <http://www.animal-welfare-indicators.net/site/>. Accessed: Apr. 05, 2016.

BAÊTA, F.C.; SOUZA, C.F. Ambiência em edificações rurais: conforto animal. Viçosa: Universidade de Viçosa (UFV), 2010. 269p.

BARROSO, F.G. et al. Social hierarchy in the domestic goat: effect on food habits and production. Applied Animal Behaviour Science, v.69, p.35-53, 2000. Available from: <http://www. sciencedirect.com/science/article/pii/S0168159100001131>. Accessed: Apr. 21, 2016. doi: 10.1016/S0168-1591(00)00113-1.

BATTINI, M. et al. Invited review: Animal-based indicators for on-farm welfare assessment for dairy goats. Journal of Dairy Science, v.97, p.1-24, 2014. Available from: <http://www. journalofdairyscience.org/article/S0022-0302(14)00644-4/pdf>. Accessed: Apr. 10, 2016. doi: 10.3168/jds.2013-7493. 
BATTINI, M. et al. Hair coat condition: A valid and reliable indicator for on-farm welfare assessment in adult dairy goats. Applied Animal Behaviour Science, v.123, p.197-203, 2015. Available from: $<$ http://www.sciencedirect.com/science/article/pii/ S0921448814003782>. Accessed: Apr. 10, 2016. doi: 10.1016/j. smallrumres.2014.12.009.

BERG, W. et al. A scoring system for coat and tail condition in Ringtailed Lemurs, Lemur catta. American Journal of Primatology, v.71, p.183-190, 2009. Available from: <http:// onlinelibrary.wiley.com/doi/10.1002/ajp.20652/abstract $>$. Accessed: Apr. 29, 2016. doi: 10.1002/ajp.20652.

BLOKHUIS, H.J. et al. The Welfare Quality ${ }^{\circledR}$ project and beyond: safeguarding farm animal well-being. Acta Agriculturae Scandinavica, Section A -Animal Science, v.60, p.129-140, 2010. Available from: <http://www.tandfonline.com/doi/abs/10 $.1080 / 09064702.2010 .523480>$. Accessed: Apr. 15, 2016. doi: $10.1080 / 09064702.2010 .523480$.

BRASIL, L.H.A. et al. Efeitos do estresse térmico sobre a produção, composição química do leite e respostas termorreguladoras de cabras da raça Alpina. Revista Brasileira de Zootecnia, v.29, n.6, p.1632-1641, 2000. Available from: <http://www.scielo.br/ scielo.php?script=sci_arttext\&pid=S1516-35982000000600006>. Accessed:Apr. 13, 2017. doi: 10.1590/S1516-35982000000600006.

BRITO, D.R.B. et al. Ectoparasite in goats and sheep folks from Alto Mearim and Grajaú microregion, State of Maranhão. Brazilian Journal of Veterinary Parasitology, v.14, p.59-63, 2005. Available from: <http://www.ncbi.nlm.nih.gov/pubmed/16153346>. Accessed: May 10, 2016.

BROOM, D.B.; FRASER, A.F. Comportamento e bem-estar dos animais domésticos. Barueri: Manole, 2010. 438p.

CODE OF WELFARE. Animal welfare (goats). Wellington: National Animal Welfare Advisory Committee, 2012. 48p.

CODEVASF. Manual de criação de caprinos e ovinos. Brasília: Instituto Ambiental Brasil Sustentável (IABS), 2011. 142p.

DONOFRE, A.C. et al. The importance of the welfare of animals farm to consumers of Piracicaba - SP/Brazil. In: SIMPÓSIO DE SUSTENTABILIDADE E CIÊNCIA ANIMAL, 3., 2013, Pirassununga, SP. Proceeding... Pirassununga: SIMPÓSIO DE SUSTENTABILIDADE E CIÊNCIA ANIMAL, 2013. Available from: <http://sisca.com.br/resumos/SISCA 2013 069.pdf $>$. Online. Accessed: Apr. 29, 2016.

EMBRAPA. Caprinos e ovinos de corte. Brasília: Embrapa Informação Tecnológica, 2005. 1v.

FAO STATISTICAL YEAR BOOK (FAOSTAT). World food and agriculture. Rome, 2017. Production of goats in the world. Available from: < http://www.fao.org/faostat/en/\#data/QA/visualize>. Online. Accessed: Apr. 01, 2016.

FILGUEIRA, T.M.B. et al. Epidemiologic and sanitary aspects of farming goats at the Chapada do Apodi regions. Revista Verde, v.4, p.64-67, 2009. Available from: <http://www.gvaa.com.br/ revista/index.php/RVADS/article/viewFile/172/172>. Accessed: May 08, 2016.

HOLANDA JÚNIOR, E.V.; MARTINS, E.C. Análise da produção e de mercados de produtos caprinos e ovinos: o caso do território do sertão do Pajeú em Pernambuco. Separatas, 2007. Available from: <http://ainfo.cnptia.embrapa.br/digital/bitstream/ CNPC/20627/1/94.pdf.>. Online. Accessed: May 06, 2016.

IBGE. Semiárido. 2005. Accessed: april 04. 2017. Online. Available from: <http://www.ibge.gov.br/home/geociencias/ geografia/semiarido.shtm?c=4>.

IBGE. Municipal livestock production. Rio de Janeiro: IBGE, 2014. 36p.

JORGENSEN, G.H.M. et al. Feed intake and social interactions in dairy goats - The effects of feeding space and type of roughage. Applied Animal Behaviour Science, v.107, p.239-251, 2007. Available from: $<$ http://www.appliedanimalbehaviour.com/article/ S0168-1591(06)00343-1/pdf $>$. Accessed: Apr. 16, 2016. doi: 10.1016/j.applanim.2006.10.007.

LICKLITER, R.E. Behavior associated with parturition in the domestic goat. Applied Animal Behaviour Science, v.13, p.335345, 1985. Available from: <http://www.sciencedirect.com/science/ article/pii/0168159185900139>. Accessed: Apr. 25, 2016. doi: 10.1016/0168-1591(85)90013-9.

MATTIELLO, S. et al. Avoidance distance test in goats: a comparison with its application in cows. Small Ruminant Research, v.91, p.215-218, 2010. Available from: <http://www. smallruminantresearch.com/article/S0921-4488(10)00068-4/pdf >. Accessed: Apr. 24, 2016. doi: 10.1016/j.smallrumres.2010.03.002.

MCINERNEY, J.P. Animal welfare, economics and policy. London: DEFRA, 2004. 52p.

MELO, L.E.H. et al. Occurrence and characterization of tuberculosis in dairy goats bred in the state of Pernambuco, Brazil. Pesquisa Veterinária Brasileira, v.32, p.831-837, 2012. Available from: <http://www.pvb. com.br/pdf_artigos/17-09-2012_08-48Vet\%201224_2628\%20LD.pdf $>$. Accessed: Apr. 23, 2016. doi: 10.1590/S0100-736X2012000900003.

NOGUEIRA, D.M. et al. Artrite encefalite caprina viral: um alerta aos produtores. Petrolina: Embrapa Semiárido, 2009. 142p. (Comunicado Técnico, 139).

PINHEIRO, R.R. et al. Aspectos epidemiológicos da caprinocultura cearense. Arquivo Brasileiro de Medicina Veterinária e Zootecnia, v.52, p.1-14, 2000. Available from: <http://dx.doi. org/10.1590/S0102-09352000000500021>. Accessed: May 05, 2016. doi: 10.1590/S0102-09352000000500021.

PUGH, D.G. Sheep and goat medicine. Philadelphia: Saunders, 2002. 1v.

RUFFIN, D.C. Mycoplasma infection in small ruminants. Veterinary clinics of North America: food animal practice, v. 17, n.2, p. 315-332, 2001. Accessed: June 28, 2017.

SCHALY, L.M. et al. Percepção do consumidor sobre bem-estar de animais de produção em Rio Verde, GO. PUBVET, v.4, p.18, 2010. Available from: <http://www.pubvet.com.br/uploads/7e8 feb0e14d7bece67cb14a9cc12a21a.pdf>. Accessed: Apr. 12, 2016.

SEBRAE. Manejo de caprinocultura. Recife: SEBRAE/PE, 2000. 35p.

SEBRAE. Manejo básico de ovinos e caprinos. Brasília: SEBRAE/DF, 2009. 146p. 
SMITH, M.C.; SHERMAN, D.M. Goat medicine. Iowa: WileyBlackwell, 2009. 2v.

SOUZA,A.M.S. etal. Ocorrência de cicatrizes e abcessos causados pela Linfadenite caseosa em caprinos do rebanho da Embrapa Semiárido. In: JORNADA DE INICIAÇÃO CIENTÍFICA DA EMBRAPA SEMIÁRIDO, 214, Petrolina, PE. Proceedings... Petrolina: EMBRAPA SEMIÁRIDO, 2014. p.325-330. Available from: <http:// ainfo.cnptia.embrapa.br/digital/bitstream/item/122429/1/Resumo-46. pdf $>$. Accessed: Apr. 20, 2016.

SUDENE. Semiárido - Superintendência do Desenvolvimento do Nordeste (SUDENE). 2016. Available from: <http://www.sudene. gov.br/area-de-atuacao/semiarido-e-regiao-nordeste>. Accessed: Apr. 12, 2017.

VILLAQUIRAN, M. et al. Body condition scores in goats. United States: American Institute for Goat Research, 2004. Accessed: Apr.
28. 2016. Online. Available from: $<$ http://www2.luresext.edu/goats/ research/BCS_factsheet.pdf>.

VOLTOLINI, T.V. et al. Principais modelos produtivos na criação de caprinos e ovinos. In: VOLTOLINI, T.V. Produção de caprinos e ovinos no Semiárido. Petrolina: EMBRAPA SEMIÁRIDO, 2011. Cap.9, p.219-232.

WELFARE QUALITY. Assessment protocol for cattle, 2009. Online. Available from: $<$ http://www.welfarequality.net/network/45848/7/0/40>. Accessed: Apr. 05, 2016.

WEMELSFELDER, F. et al. The spontaneous qualitative assessment of behavioural expressions in pigs: first explorations of a novel methodology for integrative animal welfare measurement. Applied Animal Behaviour Science, v.67, p.193-215, 2000. Available from: <http://www. appliedanimalbehaviour.com/article/S0168-1591(99)00093-3/pdf $\$$. Accessed: Apr. 23, 2016. doi: 10.1016/S0168-1591(99)00093-3. 